\title{
Widening landscapes of TV storytelling in the digital media environment of the 21 st century
}

\author{
Milly Buonanno \\ Sapienza Università di Roma \\ milly.buonanno@uniroma1.it
}

Submission date: February 2018

Accepted date: March 2018

Published in: June 2018

Recommended citation: BUONANNO, M. (2018). "Widening landscapes of TV storytelling in the digital media environment of the 21 st century". Anàlisi. Quaderns de Comunicació $i$ Cultura, 58, 1-12. DOI: <https://doi.org/10.5565/rev/analisi.3133>

\begin{abstract}
In this paper I intend to revisit from a critical perspective some issues related to the contemporary landscape of fictional TV storytelling: scripted shows whose consumption and reputation have witnessed significant changes in the 21st century. My interest focuses on what I call "narrative plenitude", the exceptional profusion of serialized fictions that are now available, anytime, anywhere, on the myriad of channels and platforms in the ever-expanding media environment. In this context, priority attention will be given in the article to the case of Netflix. In particular, I will try to unravel the coexisting mixture of gains and losses embodied in key aspects of the modus operandi embraced by the world's leading streaming platform.

Then I will address the problematic readiness of contemporary television studies to concentrate a great deal of scholarship on just a select body of scripted shows, which come under the category of 'prestige TV'. I join the dialogue among others in the field who take issue with patterns of choice largely based on the questionable cultural divide between quality niche TV and ordinary broadcast programming. Furthermore, I make the claim that this tendency fails to account for the unprecedented amplification of the contemporary landscape of storytelling, as if television studies "can't see the forest for the trees".
\end{abstract}

Keywords: storytelling system; narrative plenitude; Netflix; prestige TV

Resum. Ampliar l'escenari de la narració televisiva en l'ecosistema mediàtic digital del segle XXI

En aquest article pretenc tornar a examinar des d'una perspectiva crítica alguns temes relacionats amb l'escenari actual de la narrativa televisiva de ficció: els programes de ficció amb una producció, consum i reputació que han estat testimonis de canvis significatius en la dècada dels 2000. El meu interès se centra en el que anomeno "plenitud narrativa», 
la profusió excepcional de ficcions seriades que ara estan disponibles, en qualsevol moment i a qualsevol lloc, en la miríada de canals i plataformes de l'entorn de mitjans en expansió constant. Referent a això, en l'article es pararà atenció prioritàriament al cas de Netflix. En particular, tractaré de desentranyar la mescla coexistent de guanys i pèrdues com a aspectes clau del modus operandi adoptat per la plataforma de transmissió líder mundial. Després abordaré la disposició problemàtica d'una gran quantitat d'estudis de televisió contemporanis que es concentren únicament en un corpus concret de programes de ficció, que entren dins la categoria de «televisió de prestigi». M'afegeixo a la discussió de l'àmbit d'estudi d'autors que discrepen dels patrons d'elecció basats en gran manera en la dubtosa divisió cultural entre la televisió de nínxol de qualitat i la programació de transmissió en obert. A més, afirmo que aquesta tendència no explica l'amplificació sense precedents de l'escenari contemporani de la narrativa televisiva. Sembla que als estudis de televisió «els arbres no ens permeten veure el bosc».

Paraules clau: narració mediàtica; plenitud narrativa; Netflix; televisió de prestigi

Resumen. Ampliando el escenario de la narración televisiva en el ecosistema mediático digital del siglo XXI

En este artículo pretendo volver a examinar desde una perspectiva crítica algunos temas relacionados con el actual escenario de la narrativa televisiva de ficción: los programas de ficción cuya producción, consumo y reputación han sido testigos de cambios significativos en la década de los 2000. Mi interés se centra en lo que llamo «plenitud narrativa», la profusión excepcional de ficciones seriadas que ahora están disponibles, en cualquier momento y en cualquier lugar, en la miríada de canales y plataformas del entorno de medios en constante expansión. A este respecto, se prestará atención prioritaria en el artículo al caso de Netflix. En particular, trataré de desentrañar la mezcla coexistente de ganancias y pérdidas como aspectos clave del modus operandi adoptado por la plataforma de transmisión líder mundial. Luego abordaré la disposición problemática de una gran cantidad de estudios de televisión contemporáneos que se concentran únicamente en un corpus concreto de programas de ficción, que entran dentro de la categoría de "televisión de prestigio». Me sumo a la discusión del ámbito de estudio de autores que discrepan de los patrones de elección basados en gran medida en la dudosa división cultural entre la televisión de nicho de calidad y la programación de transmisión en abierto. Además, afirmo que esta tendencia no explica la amplificación sin precedentes del escenario contemporáneo de la narrativa televisiva. Parece que en los estudios de televisión «los árboles no nos permiten ver el bosque».

Palabras clave: narración mediática; plenitud narrativa; Netflix; televisión de prestigio

\section{From central to polycentric storytelling system}

I will start by briefly reconstructing the major shifts that television has undergone, from broadcast scarcity to the current age of so-called digital plenitude (Ellis, 2000; Buonanno, 2008). This is not to digress from my intent to share some thoughts and critical considerations on the novelty of the present time. But novelty and innovation hardly ever happen as an isolated event (and I shall purposely avoid the 'revolution' moniker), but is instead a process that has been unfolding over time. Where we are now - a fluid position that 
remains open to further developments - is premised upon shifts that have paved the way for new modes of creation, distribution and consumption of TV storytelling to emerge later.

"Numberless are the world's narrative". The famous opening of the highly influential Introduction to the structural analysis of narrative by Roland Barthes (1966) is worth quoting here for its double pertinence to the topics of my discourse. First: the author goes on from this opening statement to provide a compelling reminder that, as human beings, we have a long-standing historical familiarity with living in an environment saturated with narratives that are supplied by an array of different sources. Secondly: while mentioning almost every storytelling form, from myths and legends to epics, history, novels, cinema, comics, news, conversation and much more, Roland Barthes totally overlooked television. It seems as if TV had not even entered the sphere of perception of such a cultured individual and sophisticated intellectual. And yet he was writing in the mid-sixties, when broadcast television was already well established in western society. But there was a deeply rooted low repute and denigration of the medium among the culturati and literati circles.

Pace Roland Barthes, broadcast television soon established itself as "the central storytelling system" (Newcomb, 1988: 89) of modern societies in the second half of the 20th century. Its centrality was acknowledged and conceptualized by the founding fathers of television studies, like Raymond Williams (1974), John Fiske and John Hartley (1978), and Horace Newcomb (1983, 1988). As stated by Fiske and Hartley, who coined the term 'bardic function of television': "The bardic mediator occupies the centre of its culture: television is one of the most highly centralized institutions in modern society" (1978: 86).

The transition to the multichannel environment happened at different paces in different places - in the US from the mid-1980s (Lotz, 2007), in Italy not until the late 1990s. However, it was a largely accomplished fact by the early 21st century, and brought about a dramatic change that goes well beyond the pluralization of TV channels and the resulting break-up and fragmentation of the audience.

More importantly, the multichannel transition largely helped lay the foundation for the 'cultural divide' between the 'old' broadcasting, with its mixed (mass) audience of ordinary viewers, and the 'new' narrowcasting television, blessed with its select niche-audience of educated and affluent viewers (since then the most valuable and considered viewership). This divide was destined to widen with the advent of delivery platforms.

In the 21 st century, a growing number of digital streaming platforms - or portals, as recently suggested by Amanda Lotz (2017) - has joined what was an already crowded TV landscape. As Nick Couldry contends, "we now experience a media manifold, comprising a complex web of delivery platforms" (2012: 16). Following in the footsteps of narrowcasting networks, these platforms, which might be regarded as the channels of internet-distrib- 
uted television, have in turn stepped into the field of the original production of narratives, to cultivate and multiply their own segments of the audience, in addition to fostering new consumer practices that are allowed or instigated by digital technologies.

As a consequence of this process, television and the storytelling system have been re-configured: the televisual bard no longer sits "at the centre of its culture", since it has morphed into an interconnected plurality of channels, screens, and modes of delivery (and modes of narration) that outline the contours of a 'polycentric storytelling system', where a host of diverse storytellers make their voices heard.

\section{Experiencing a 'narrative plenitude'}

Back to Roland Barthes. Now more than ever the claim that the "numberless are the world's narratives" deeply resonates with our consciousness of contemporary individuals who are experiencing 'a narrative plenitude' of sorts, especially due to the flurry of series and serials that is emanating from the widening television system: the 'television at large', including both linear and internet-distributed modes, and a mix of two.

Led by the leading streaming platform, Netflix - which has announced plans to reach 1,000 hours of original production in the very near future these portals are at the forefront of this transnational trend that, in the United States alone, saw the number of original scripted shows on offer rise by $168 \%$ from 2002 to 2017, when they numbered 487 (Hanson, 2018). Outside of the US, the unprecedented bonanza of programming on offer is becoming the new norm wherever the advent of further channels and platforms raises the need and offers the opportunity and the advantage to expand the supply of TV fiction, be this in the form of original productions or licensed imports (which are most often the majority).

The escalating amount of new scripted shows delivered by the multiple players in the 'polycentric storytelling system" has been labeled 'Peak TV' (by the CEO of FX network, John Landgraf), with clear allusion to the risk of an overwhelming and ultimately untenable excess of stories available to viewers.

Although it makes sense to question the sustainability in the medium-long term of a trend that requires an enormous amount of (typically not unlimited) resources of talent and money, to mention just the basics, other points need our priority attention.

It is worth noting in this regard that the intensified provision of new scripted shows - which not surprisingly occurs mostly in the field of narrowcasting television and streaming services - is only in part the natural consequence of a burgeoning number of players who, sooner or later, take the road of original production to create or reshape a distinctive brand in order to gain recognizable visibility within an over-crowded media environment. Most importantly, in significant and influential cases we are confronted by a peculiar business strategy, and one that is especially pursued by subscription 
streaming platforms, that is meant to address multifarious sets of audiences - rather than the mass audience addressed by broadcast television, or the specific niche audience targeted by narrowcast channels.

This "conglomerated niche" strategy, in the rapidly adopted definition proposed by Amanda Lotz (2017), is based on the conception and treatment of the subscriber base as an assemblage of heterogeneous subsets of viewers; accordingly, the catalogue of streaming titles is created and frequently refreshed by providing an assorted plurality of original (and licensed for that matter) shows, so as to meet the diverse demands and tastes of the multiple segments of the viewing public. It is precisely this that has allowed Netflix to reach a subscriber base of 110 million worldwide in 2017 and to exceed \$11 billion in revenues: a useful reminder that the exhilarating narrative plenitude of the present time is flourishing in an environment of heightened competition between an array of delivery platforms that pursue their commercial interests by capturing the attention and time of an increasingly sliced and diced aggregate of viewers and subscribers.

This is certainly not to demonize competition and commercial interests, but we do need to avoid romanticizing the 'creative explosion' of narrative imagination and the booming production and supply of TV fiction in the second decade of the 21 st century.

Segmentation is a key issue for understanding the rationale behind the wealth of scripted shows that are being delivered these days on an unheard-of scale, especially in the expanding domain of internet-distributed television. To put it simply, whereas a mass audience logic allows for "a small number of programs that target large facets of the population" (Novak, 2017: 165) [...] the logic of audience fragmentation seeks instead "many programs that target small facets of the population" (ibidem).

On the one hand, such a logic - whose reach evidently spans far beyond television and media in general - is hardly new, as it can be traced back to the 'nichification' of audiences brought about by the multichannel transition that I recalled above. On the other hand, I am very far from wishing to validate the assumption that the divisive logic of audience fragmentation has made the aggregative broadcasting policy to "target large facets of the population" definitively obsolete. I do not embrace this assumption, not least because I live in a country (Italy) where the umpteenth seasons of popular series (Il commissario Montalbano, 1999-; Don Matteo, 2000-) airing on the flagship channel of public television still manage to appeal to a mass audience of 8-10 million viewers.

The segmentation of viewers has nonetheless become established and has emerged as the new norm, mostly, although not exclusively, among OverThe-Top content providers. But no one has pushed the segmentation envelope as far as Netflix, which so far has sliced its subscriber base into as many as 2000 'taste clusters' ('taste communities', in the company's more fashionable wording), according to the viewing preferences of individual consumers that are subject to continuous monitoring by the platform. Keeping track of 
viewer habits is instrumental to the extreme content customization that Netflix pursues.

Taste, and no longer the demographic data that has been traditionally used to create and address niche audiences, has thus become the sole differentiating and hyper-multiplying factor. A large quantity and a wide variety of contents are required in order to feed the tastes of myriad clusters.

Netflix's modus operandi has substantially helped to widen the landscape of storytelling and has expanded access to what appears to be an almost boundless cornucopia of television narratives to an unprecedented degree. This certainly generates the valuable gain of a greater range of choice that discloses and (seemingly) maintains the historical promise - left unfulfilled by television as we have known it - to 'give viewers what they want'.

Still in terms of gains, it is worth pointing out that the current wealth of narratives on offer has opened a special window of opportunity that was barely available in the past. I am referring here to the shift that can be observed in the space of what has long been known as 'the international flow of television programs'. This may be expressed by slightly rephrasing Bartes' quotation: "numberless are the narratives from the world". The rephrasing is meant to acknowledge what in my view - id est from the perspective of a scholar who has long elaborated on the notion and the cultural importance of "travelling narratives" (Buonanno, 2008) - is to be considered a significant re-configuration of the geography of television storytelling. The hunger of myriad channels and platforms for contents, and which original productions would never be able to satisfy, along with - especially in the case of Netflix - strategies for international expansion that involve including in the portfolio fiction from different territories, have in fact helped to widen the geo-cultural spectrum of the narratives made available to viewers. Whereas, until recently, in a great many parts of the world scripted shows from the US provided almost the only transnational addition or alternative to local programming, it has now become possible for shows originating from a wide and diverse range of places to spread internationally, and for audiences to discover and explore unknown landscapes of travelling narratives. This is not to lose sight of the big picture and disregard the truth that productions originating from the US (and to a lesser extent the UK) - the "Anglo-American media connection", as dubbed by Jeremy Tunstall (1999) - still take the lion's share of global circulation. However, the fact that narratives from emerging creative districts - Scandinavia, Turkey, Israel, South Korea, Mexico, Brazil, Italy and more now enjoy wide (albeit still limited) international distribution, and can increase the viewers' curiosity and interest, is a detail that should not be overlooked.

Availability is not enough, of course. It remains to be seen to what extent, and in what contingencies and circumstances, the availability of 'the other's narratives' translates into viewer interest, choice and engagement. The potential for cultural encounters with stories from elsewhere, offered by the new possibilities brought about by shifting dynamics in the international flow of 
television, could ultimately remain largely unexplored. Especially in the case of Netflix, whose strategy is hardly encouraging for any incursion into unfamiliar territories of storytelling (I will return to this point in the next section), it is not unlikely that the addition of some amount of 'narratives from the world' is more of a signpost for domestic content for local subscribers than a call for cosmopolitan viewership.

\section{Reason for concern}

Unless one subscribes to a discredited idea of digital exceptionalism, it should come as no surprise that the potential benefits - namely unlimited access, free choice and control - related to the prerogatives of a well-furnished streaming platform go hand in hand, and are in constant tension, with limitations, a predetermined set of choices and surveillance. As Graeme Turner cogently remind us, the major shifts and breaks that are reshaping the media environment of today incorporate a "complex mixture of gains and losses" (Turner, 2016:50), which need to be unraveled.

Due to limitations of space in such a short article, I shall limit myself to indicating the interconnection between audience hyper-segmentation and the systematic tracking of individual viewer behavior as a highly problematic and concern-raising aspect of the Netflix paradigm. It may be worth pointing out that I make no claim to be saying anything new here. On the contrary, I am interested in showing evidence that the issue has been addressed and discussed in depth in recent years - with or without specific regard to Netflix by influential media scholars (to mention just a few: Couldry and Turow, 2014; Newman, 2014; Webster, 2014; Turner, 2016; Barker and Wiatrows$\mathrm{ki}, 2017)$. Nonetheless there are good reasons to return to the question again, as the major consensus surrounding digital media and platforms, together with the resounding self-legitimating narratives dispensed by powerful media companies and industry players, has greatly helped discourses of benefits and empowerment to prevail over awareness and concerns related to drawbacks and surveillance. A proclivity to "uncritically accept what we can now more confidentially determine was in fact 'industry spin"” (Turner, 2016: 5), or to give pride of place to the progressive and benevolent face of the industrial and cultural forms generated by the new technologies, has also taken hold in some quarters of media studies.

Taking a critical stance instead, Nick Couldry and Joseph Turow have expressed and articulated concern over the implication for democracy of the progressive decline "of shared public reference points [that] go beyond news to include a wide range of materials - fiction stories, images and songs" (2014: 1711). Although incidental within a discourse that is mainly concerned with marketing and advertising, the mention of fiction stories significantly acknowledges storytelling as a source of sharedness and commonality, whose restricting reach in the digital media system plays a part in "the gradual erosion of a common arena of discourse" (2014: 1712). This erosive impact 
is further intensified by the deployment of customization tactics that overcome segmentation on the path towards major personalization, which is enabled and enhanced by the continuous monitoring of consumer behavior.

Granted, segmentation and customization - by now commonplace in a great many areas of business - are hardly exclusive to Netflix. Among media players, however, the streaming platform has pushed the envelope by fragmenting a huge subscriber base into thousands of micro-niches that, despite some margin for overlap, are hardly suitable for sharing common arenas of taste and confrontation. "Taste-sphericules" - to borrow the definition offered by Todd Gitlin two decades ago in an influential discussion on the implosion of the public sphere (1998) - would seem a more appropriate term to identify what the company labels taste-communities.

Extremely fine-tuned tactics are deployed (and proudly boasted) by Netflix on the personalization side too: notifications, recommendations, interfaces, the browsable catalogue of content, are all closely calibrated to the tracked preferences of each individual customer within the taste group that $s /$ he belongs to. Thus different people are offered a different "best experience" of Netflix and different access to content. More importantly, as convincingly argued by Sarah Arnold, what counts as personalization is the product of a measurement system that totally disregards a user's context, experience and identity: "a system that strips away human agency, personality and character" (Arnold, 2017: 55), impoverishing like never before the conception of the viewer whose profile is merely inferred from the digital traces of his/her activity on the platform.

In this context, it is also important to note that the data and algorithm system used by Netflix is aimed at generating predictive assumptions about what people are more likely to watch, based on previous viewing behavior. Accordingly, subscribers are addressed by an array of personalized recommendations that suggest that they should confirm consistent patterns of choice ("because you have watched this..."), by selecting what looks appealing from an algorithm-preselected list of shows. If Netflix's statements can be trusted, albeit with all reservations towards the industry's self-narratives, recommendations drive $75 \%$ of viewing choice. Regardless of whether this is true or not, it is not my full intention to affirm that audiences are left defenseless at the mercy of Netflix's manipulative influences. This is neither to buy into any rhetoric of an empowered audience in the digital age, nor to rely on the unquestionable principle that viewers are still free to skip or discard suggestions and recommendations and follow instead different paths of choice or to wander through the seemingly endless catalogue of narratives on offer, in search of serendipity. It is rather to contend that recommendations are likely to prove influential in subtle and unsuspected ways (also) because they perfectly accommodate and pander to moods, demands and expectations of immediacy triggered by the contemporary "culture of speed" (Tomlinson, 2007). They allow users to save the scarce and precious resource of time, and to avoid or lessen the fatigue of making choices and the burden of the uncer- 
tainties related with decision-making. It is not surprising that the vast majority of users accept, follow and even welcome recommendations, as these appear to be 'facilitators' of viewing activity, while in actual fact they put a damper on personal agency. Likewise, by being able to drive users' choices, the recommendation system does something more than accommodate personal preferences: it also shapes viewer behavior, whose detailed monitoring is therefore destined to generate predictive assumptions that postulate preferences determined, to a lesser or greater extent, by the same system.

It seems undisputable, therefore, that Netflix - as the spearhead of an established trend - manages to shape, drive, divide and govern habits and experiences related to the consumption of television narratives. This coexists with and contradicts beliefs and expectations of a plentiful and unrestricted freedom of choice, potentially enhanced by the expanding landscape of storytelling that Netflix itself helps to bring into being.

\section{The tree hiding the forest}

It makes sense at this point to ask how television studies relate to and account for the expanding landscape of storytelling in the present media environment. How does this field of scholarship manage to cope with an overwhelmingly large mass of available narratives?

As television scholars, we are by necessity forced to recognize and come to terms with the sheer limitation of our capacity to get a comprehensive grasp of such a hyper-saturated landscape. More than ever, selection is mandatory and plays a key role, as the way it is performed following specific patterns of inclusion/exclusion helps to shape and inflect the scholarly representation of the state of the art.

As I said above, problematic practices have been put in place by the streaming giant Netflix to drive subscribers to select and choose what they like and want to watch. In addition, a sustainable claim can be made that the widely embraced criteria of contemporary television scholars to select the shows they will write and lecture about also appears to be problematic.

Indeed, the irrefutable need for selection can hardly motivate or explain the bias toward focusing scholarly research and analysis on just one body of narratives from among the much broader and varied ensemble. A retrospective look at television studies from early 2000s onwards clearly demonstrates that, when it comes to TV storytelling, the vast majority of studies, publications and conversations in the field has been concerned with one and only one kind of narrative: those labeled 'Prestige TV' (I purposely avoid the ambiguous label 'quality' with which it has often been conflated: Buonanno, 2013). This peculiar bias is precisely what - quoting a famous article by Francois Truffaut on post-war French cinema - I define as "a certain tendency" (Truffaut, 1954) of contemporary television studies.

With very few exceptions (see Lost), so-called 'Prestige TV' is the prerogative of narrowcast channels - HBO, FX, AMC, Showtime, Sky Atlantic - 
and streaming platforms - Netflix, of course, and increasingly Amazon and Hulu. Scripted shows included in the category boast a cluster of distinctive hallmarks - originality, experimentation, cutting-edge, controversial topics, complexity, visual distinctiveness, film style, genre mashup and more besides - that set them apart from all the rest, first and foremost the tradition of broadcast television drama whose disparaged conventional approach, restrained creativity, and poor (or so considered) aesthetics are challenged by the unconventionality, stunning creative freedom and artform status of prestige shows. Prestige TV has thus become the canon of 21 st century TV drama and, to borrow a word from historical jargon, has been literally monumentalized by the amount of scholarly writings and conversations, together with fan enthusiasm, critical acclaim and industry awards.

I am certainly not denying or questioning the fact that the range of narratives delivered in the first two decades of the 21 st century has often resulted in excellent television, pushing the aesthetic and representational envelope much further beyond the more conventional boundaries of traditional TV drama. One considers, for instance, the antiheroic trend that has fueled intriguing viewing pleasure as much as intellectual speculations and ethical dilemmas, by way of narratives inhabited by complex (mainly male) characters endowed with moral ambiguity, damaging flaws, enduring strength, unapologetic wickedness and yet the relatable qualities that work together to shape a conflicted and nuanced, despicable and admirable antiheroic figure. The not-so-holy antiheroic trinity formed by The Sopranos, Breaking Bad and Mad Men, which is deemed emblematic of the golden or platinum age of television, provides a telling template for 21 st century prestige drama.

In this context, we cannot overlook, on the one hand, the gendered nature id est the masculinization of a great deal of what passes as prestige in contemporary TV drama; and, on the other hand, the scant attention paid in cultural and scholarly discourses to the less numerous but no less compelling female-centered narratives - on which I elaborated at length in the introduction to my edited collection on Television antiheroines (2017). I limit myself here to merely mentioning this point, about which I am nonetheless highly concerned, as a feminist scholar, to make it clear that what I am questioning is the role played by television studies in giving scholarly endorsement to the discursive construction that is meant to elevate one body of narratives to an unequaled zenith of relevance and cultural legitimation. It is according to this discursive construction that niche channels and streaming platforms construct and boast a cultured and artistic brand, which aims to place them at the cutting-edge of creative trends. Netflix's self-promotion, for instance, puts strong emphasis on its ability to deliver the promise of prestige, through a mixture of technological and aesthetic appeals that seek to position the streaming platform far ahead and well above ordinary television'.

The truth is that the hierarchical dichotomy - which has been emerging since the dawn of the multichannel transition - between what has significantly come to be dubbed "legacy television" and whatever medium is labeled 
"new" is still lingering and deepening, irrespective of any evidence for the persistence of broadcast television as a source and provider of meaningful, enjoyable (and also quality for that matter) narratives that have not ceased to appeal to contemporary viewers. It is not by chance that the catalogues of streaming platforms are largely reliant on scripted shows from broadcast networks. Nonetheless, as Taylor Nygaard and Jorie Lagerwey cogently contend in their introduction to the special issue that Television \& New media has recently devoted to The good wife (CBS, 2009-2016), "narrowcast and streaming series, with their flashy production and distribution practices, continue to garner the most critical celebration and leave broadcast television largely missing from discussions of post-network era quality" (2016: 108).

This may serve as a telling reminder to us that the widening landscape of contemporary TV storytelling, in addition of being segmented according to taste sphericules in the influential realm of streaming platforms, is also deeply polarized, owing to "the growing discursive divide between narrowcast channels and streaming on one hand, and broadcast network programming on the other" (Nygaard and Lagerway, 2016: 106). By focusing almost exclusively on the former while overlooking the latter, and therefore casting light only on certain corners of the landscape, critical and scholarly attention are failing in their endeavor of a wider exploration of the extended and diverse repertoire of contemporary television storytelling.

All of this has resulted in "a tree hiding the forest": a real paradox at a time when television narratives are witnessing increasing expansion and diversification, on a local and global scale.

\section{Bibliographical references}

ARNOLD, S. (2017). "Netflix and the myth of choice/participation/autonomy". In: K. MCDONALD and D. SMITH-ROWSEY (eds.). The Netflix Effect Technology and Entertainment in the 21st Century. New York: Bloomsbury, 49-62.

Barker, C. and Wiatrowski, M. (eds.) (2017). The age of Netflix. Jefferson: McFarland.

BARTHES, R. (1966). Introduction to the structural analysis of the narrative. Birmingham: Centre for Contemporary Culture Studies.

Buonanno, M. (2008). The age of television. Experiences and theories. Bristol and Chicago: Intellectbooks and Chicago University Press.

- (2013). "The transatlantic romance of television studies and the tradition of quality in Italian television drama". Journal of popular television, 3 (2), 175-189.

- (2017). Television antiheroines. Women behaving badly in crime and prison drama. Bristol and Chicago: Intellectbooks and Chicago University Press.

COULDRY, N. (2012). Media, society, world. Social theory and digital media practice. Cambridge: Polity Press.

COUlDry, N. and Turow, J. (2014). "Advertising, big data, and the clearance of the public realm: marketers' new approaches to the content subsidy". International journal of communication, 8, 1710-1726.

ELLIS, J. (2000). Seeing things. London: IB Tauris. 
Gitlin, T. (1998). "Public sphere or public sphericules?” In: T. LIEBES and J. CURRAN (eds.). Media ritual and identity. London: Routledge, 168-174.

HANSON, F. (2017). The era of peak TV continues. <http://www.dailymail.co.uk/ news/article-5242933/Peak-TV-era-continues-487-scripted-shows-2017.html> (accessed January 10th 2018).

LOTZ, A. (2007). The television will be revolutioned. New York: New York University Press.

- (2017). Portals. A treatise on internet-distributed television. Ann Arbor: Michigan Publishing.

NEWCOMB H. (1988). “One night of prime time”. In: J. CAREY (ed.). Media, myths and narrative. London: Sage.

NeWCOMB H. and HirsCH, P. (1983). “Television as a cultural forum”. Quarterly review of film studies, $8,45-55$.

NeWman, M. (2014). Video revolutions. On the history of a medium. New York: Columbia University Press.

NeWman, M. and LeVInE, E. (2011). Legitimating television. London: Routledge.

NOVAK, A. (2017). "Narrowcasting, millennials and the personalization of genre in digital media". In: C. BARKER and M. WiATROWSKI (eds.). The age of Netflix. Jefferson: McFarland, 162-181.

NYGAARD T. and LAGERWEY, J. (2016). "Broadcasting quality: re-centering feminist discourse with The Good Wife". Television \& New Media, 18 (2), 105-113.

TOMLINSON, J. (2007). The culture of speed. London: Sage.

Tunstall, J. and D. MACHIN, D. (1999). The AngloAmerican media connection. Oxford: Oxford University Press.

Truffaut, F. (1954). 'Une certaine tendence du cinéma français'. Cahiers du Ciné$m a, 4(31), 15-19$.

TURNER, G. (2016). Re-inventing the media. London: Routledge.

WeBSTER J. G. (2017). The marketplace of attention. How audiences take shape in a digital age. Cambridge: The MIT Press.

WiLliams, R. (1974). Television: technology and cultural form: London: Fontana. 